カメラでは線源の固定，操作性，スループットなど，実 用的であるとは言い難いのが現実です。これらの研究結 果を無駄にせず臨床的に活用する為には，有効な吸収補 正のアルゴリズムの研究と共に，より現実的な手法の確 立と展開が必要であると考えられます。つまり線源の固 定や交換，ソフトウェアのプロトコル化，容易な操作性 検査時間の短縮など，臨床レベルに即したハードウェア とソフトウェアのダウンサイジングが必要と考えられま す.

\section{Right Angle 型 2 枚検出器による 今後の検討}

今回新しく開発された right angle（L字）型 SPECT 装置は emission scan と transmission scan $の$ 同時収集 が可能である為, transmission scan の追加による検査時 間の増加や各 scan 間の患者の移動が改善できる. 今後,
これらの機能をベースにハード・ソフトを含めた検討を 重ねていきたい.

\section{5.まとめ}

Right angle 型 SPECT 装置による定量性向上の可能 性を検討した。 L字型に配置された 2 個の検出器はリン グガントリに固定されているため，線源の固定に都合が 良く, transmission scan の可能性が示唆された。本装置 は心臟の検査を主眼に開発されているため，従来の心筋 SPECT に比べ効率的な心臟検査を行うことが可能であ り, emission に加え, transmișsion, scatter 等の収集に も十分対応できる能力がある。

今回は，STARCAM により臨床的意義や手法の検討 を中心に行ったが，まだ十分とは言えず，さらに詳細な 実験，アルゴリズムの検討を加光，right angle型 SPECT 装置による定量性向上を今後の課題としたい.

\title{
(3)シーメンスの心臓専用コリメータ（カルディオフォーカル） の優位点と応用性について
}

\author{
武 藤 昭 男・宮 沢 正 則 \\ シーメンス旭メディテック株式会社
}

\section{1.はじめに}

一般にパラレルビーム (以下 $\mathrm{PB}$ と略記)コリメータを 用いる場合空間分解能とシステム感度を共に高めること はできない．しかし有效視野を限定するという条件つき の場合，つまりファンビーム (以下 FB と略記) やコーン ビーム (以下 $\mathrm{CB}$ と略記) コリメータを用いることにより 達成される。他方, 多検出器式ガンマカメラを用いてシ ステム感度の向上を計ることができるが，この場合はあ くまでもシングル検出器ガンマカメラに対しての向上で あり特に心臓の検查においてはカメラの数に比例した優 位性は得られず三検出器式ガンマカメラの場合ですら対 シングル比で高々 $130 \%$ の向上が得られるにすぎない.シ ーメンス社はシングル検出器式ガンマカメラを用いて充 分に三検出器式ガンマカメラに匹敵するシステム感度の 向上と空間分解能の向上が得られる心 SPECT 専用のコ リメータシステムである「カルディオフォーカル（以下 CF と略記)」を開発中であるので報告する.

\section{2. 技術内容について}

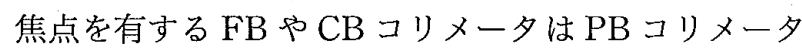
よりも感度が優れるが対象物の全体像が得られないため に載断面辺縁のアーチファクト（truncation artifact）を 画像再構成において生じる。CFコリメータでは焦点を 有しながら全体像を得て画像再構成を行なうことを特長 としているために載断面辺縁のアーチファクトは生じな い. 更に単焦点ではなく多焦点式であるので $\mathrm{FB} や \mathrm{CB}$ コリメータの場合のように有効視野に制限がない. Fig.

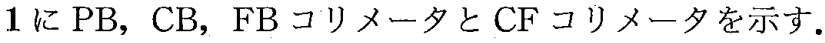
左側から夫々 $\mathrm{PB}, \mathrm{CF}, \mathrm{CB} / \mathrm{FB}$ を示すが裁断面の辺縁の

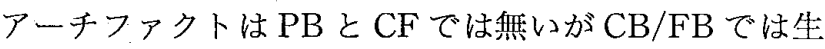
じる，有効視野は $\mathrm{PB}$ と CF では全体像をカバーするが

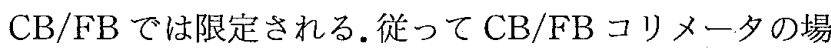
合は心 SPECT デー夕収集時に心臟は有効視野の中心に なければならない（非円軌道 $\mathrm{CNCO}$ ) 収集をすることが 好ましいが CFコリメータにおいては心臟が䈔密に有効 


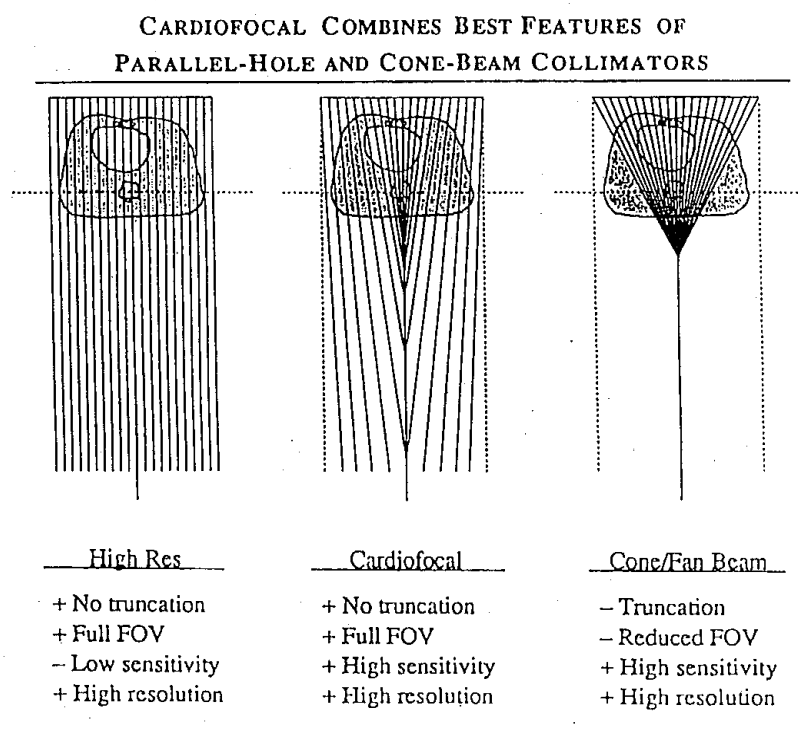

Fig. 1 各種コリメータの比較

視野の中心にある必要はなく且つ円軌道収集を行うこと ができる，空間分解能についてみるならば感度の低下を 問題にしないのであれば PB コリメータによっても向上 させることが可能であるが心 SPECT の場合は感度が重 要であるので同一空間分解能であれば CF の方が $\mathrm{PB} よ$ りも優位となる。

\section{3. 仕様について}

Fig. 2 に CF コリメー夕の断面及び側面像の概念図を 示す．多焦点式 CB コリメータでありながら全体像を得

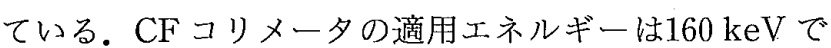
体積感度（volume sensitivity）は回転直径 $29 \mathrm{~cm}$ の場合 低エネルギ高分解能 PB コリメータの約 2 倍である. 焦
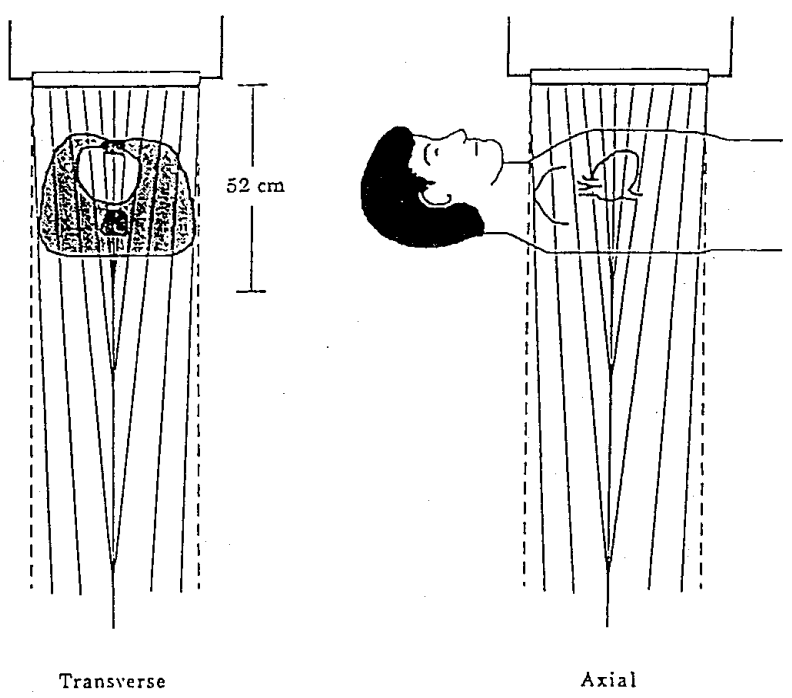

Fig. 2 カルディオフォーカルコリメータ概念図

点は52 $\mathrm{cm}$ から $6 \mathrm{~m}$ まで変化し円軌道にて 180 度及び 360 度収集が可能である，収集マトリクスは64×64及び $128 \times 128$ あるる。臟だけでなく全体像が有効視野に入 うているので心 SPECT 像の画像再構成にフィルタード バックプロジェクション法を採用できるので $\mathrm{CB}$ や $\mathrm{FB}$ コリメータの場合よりも画像計算時間は大巾に短くなる.

\section{4. まと め}

シーメンス社の開発中の CFコリメータについて報告 した: CFコリメータはハードウェアとソフトウェアが パッケージとなった技術でありシーメンス社が基本技術 の特許を保有している.

\title{
(4)高速画像ワークステーションと今後の展望
}

\author{
高 橋 宗 尊
}

(秼)島津製作所

\section{1.はじめに}

最近の核医学データは，年々大容量化の傾向にある。 スタティック，ダイナミックな収集に加え，近年ではダ イナミック SPECT 収集やR R波同期 SPECT 収集など, 従来では検查に非常に時間のかかる収集が，SPECT 尃
用装置の導入により比較的短時間に行えるようになった。 これらの検査は大容量のデータを収集するため, フィル タリング，画像再構成など，大量の繰り返し演算を高速 に行う必要がある。

PRISM シリーズのデータ処理装置である ODYSSEY スーパーコンピュータ11は, 64MIPS, 96MFLOPS 